Chemical Technology Division

\title{
EVALUATION OF THE ACCEPTABILITY OF POTENTIAL DEPLETED URANIUM HEXAFLUORIDE CONVERSION PRODUCTS AT THE ENVIROCARE DISPOSAL SITE
}

\author{
Allen G. Croff, J. Robert Hightower, and Nancy L. Ranek*
}

*Argonne National Laboratory, Argonne, Illinois

December 2000

Prepared by the OAK RIDGE NATIONAL LABORATORY

Oak Ridge, Tennessee 37831-6285 managed by

UT-BATTELLE, LLC

for the

U.S. DEPARTMENT OF ENERGY

under contract DE-AC05-00OR22725 


\section{CONTENTS}

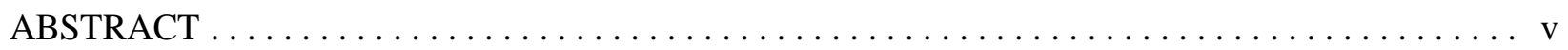

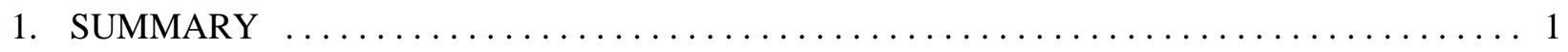

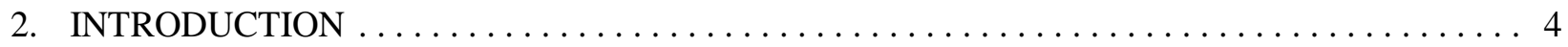

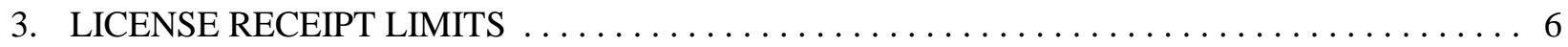

4. CLASSIFICATION OF DU PRODUCTS $\ldots \ldots \ldots \ldots \ldots \ldots \ldots \ldots \ldots \ldots \ldots \ldots$

5. ACCESS TO NON-DOE LLW DISPOSAL SITES $\ldots \ldots \ldots \ldots \ldots \ldots \ldots \ldots \ldots \ldots$

6. HISTORICAL VIEWS OF THE U.S. NUCLEAR REGULATORY COMMISSION $\ldots \ldots \ldots \ldots 11$

7. PRE-SHIPMENT SCREENING FOR REACTIVITY $\ldots \ldots \ldots \ldots \ldots \ldots \ldots \ldots \ldots \ldots \ldots$

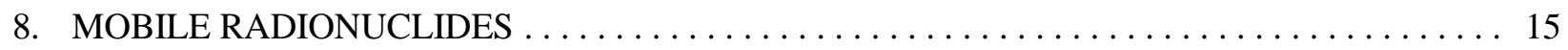

9. NATIONAL ENVIRONMENTAL POLICY ACT $\ldots \ldots \ldots \ldots \ldots \ldots \ldots \ldots \ldots \ldots \ldots$

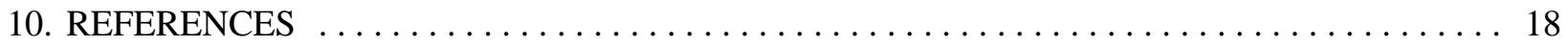




\begin{abstract}
The purpose of this report is to review and document the capability of potential products of depleted $\mathrm{UF}_{6}$ conversion to meet the current waste acceptance criteria and other regulatory requirements for disposal at the facility in Clive, Utah, owned by Envirocare of Utah, Inc.

The investigation was conducted by identifying issues potentially related to disposal of depleted uranium (DU) products at Envirocare and conducting an initial analysis of them. Discussions were then held with representatives of Envirocare, the state of Utah (which is a NRC Agreement State and, thus, is the cognizant regulatory authority for Envirocare), and DOE Oak Ridge Operations. Provisional issue resolution was then established based on the analysis and discussions and documented in a draft report. The draft report was then reviewed by those providing information and revisions were made, which resulted in this document.
\end{abstract}

Issues that were examined for resolution were (1) license receipt limits for U isotopes; (2) DU product classification as Class A waste; (3) use of non-DOE disposal sites for disposal of DOE material; (4) historical NRC views; (5) definition of chemical reactivity; (6) presence of mobile radionuclides; and (7) National Environmental Policy Act coverage of disposal.

The conclusion of this analysis is that an amendment to the Envirocare license issued on October 5, 2000, has reduced the uncertainties regarding disposal of the DU product at Envirocare to the point that they are now comparable with uncertainties associated with the disposal of the DU product at the Nevada Test Site that were discussed in an earlier report. 


\section{EVALUATION OF THE ACCEPTABILITY OF POTENTIAL DEPLETED URANIUM HEXAFLUORIDE CONVERSION PRODUCTS AT THE ENVIROCARE DISPOSAL SITE}

\section{SUMMARY}

An earlier report contained a preliminary assessment of the acceptability of the potential depleted uranium (DU) products in the form of $\mathrm{DUF}_{4}, \mathrm{DU}_{3} \mathrm{O}_{8}, \mathrm{DUO}_{2}$, and DU metal for near-surface disposal at the Envirocare facility in Clive, Utah, and the low-level waste disposal facility at the Nevada Test Site. This assessment was based on previous knowledge of the authors and preliminary review of documents relevant to waste acceptance at these sites. The report's conclusion regarding the Envirocare site was that "the current waste acceptance criteria suggest that the acceptability of depleted uranium hexafluoride conversion material for disposal at Envirocare of Utah is questionable. Further investigation is required before a definitive determination can be made" [Croff 2000, p. 9]. The purpose of this report is to document the more thorough investigation suggested in the conclusion of the previous report.

The investigation was conducted by identifying issues potentially related to disposal of DU products at Envirocare and conducting an initial analysis of them. Discussions were then held with representatives of Envirocare, the state of Utah (which is a NRC Agreement State and, thus, is the cognizant regulatory authority for Envirocare), and DOE Oak Ridge Operations. Provisional issue resolution was then established based on the analysis and discussions and documented in a draft report. The draft report was reviewed by those providing information and revisions were made, which resulted in this document.

The following were determined at the outset to not be issues regarding the acceptability of DU product disposal at the Envirocare site and were not subject to further investigation as described above:

- Potential generation of small amounts of aqueous HF from the interaction of water with $\mathrm{DUF}_{4}$.

- Criticality issues and limits on the concentrations of special nuclear materials.

- License Receipt Limits (i.e., maximum acceptable concentrations) for any radionuclide other than DU.

- Possibility of disposal capacity shortage at Envirocare.

Table 1 summarizes the issues that were investigated, and the resolution of each. 
The conclusion of this analysis is that an amendment to the Envirocare license issued on October 5, 2000, has reduced the uncertainties regarding disposal of the DU product at Envirocare to the point that they are now comparable with uncertainties associated with the disposal of the DU product at the Nevada Test Site that were discussed in an earlier report. 
Table 1. Issue identification, evaluation, and disposition related to DU product disposal at Envirocare

\begin{tabular}{|c|c|c|}
\hline Issue & Evaluation & Disposition \\
\hline $\begin{array}{l}\text { License Receipt Limits: Limits on } \\
\text { the maximum activity of DU that is } \\
\text { acceptable at Envirocare would } \\
\text { exclude a significant-to-major fraction } \\
\text { of the DU products from disposal at } \\
\text { Envirocare. }\end{array}$ & $\begin{array}{l}\text { As a result of a new amendment to the Envirocare license, } \\
\text { DU products are acceptable for disposal in the Class A cell } \\
\text { at Envirocare because activity limits do not apply to DU } \\
\text { placed into the Class A cell. }\end{array}$ & Issue closed. \\
\hline $\begin{array}{l}\text { DU Product Classification: The DU } \\
\text { product must be Class A waste to be } \\
\text { acceptable at Envirocare. After long } \\
\text { decay times, }{ }^{226} \text { Ra concentrations } \\
\text { exceed Class A limits. }\end{array}$ & $\begin{array}{l}\text { Determination of whether waste is Class A is based on the } \\
\text { waste composition when received by Envirocare. At the } \\
\text { time of receipt by Envirocare, the }{ }^{226} \mathrm{Ra} \text { in the DU products } \\
\text { would easily meet Class A limits. }\end{array}$ & Issue closed. \\
\hline $\begin{array}{l}\text { Use of Non-DOE Disposal Sites: To } \\
\text { satisfy the requirements of DOE Order } \\
435.1 \text { the manager of the cognizant } \\
\text { DOE field element (DOE-OR in this } \\
\text { case) must grant an exemption from } \\
\text { having to use a DOE site for LLW } \\
\text { disposal. }\end{array}$ & $\begin{array}{l}\text { The issue of granting an exemption cannot be resolved } \\
\text { without a specific application for an exemption. Such a } \\
\text { request could occur de facto in the form of the response to } \\
\text { the Request for Proposals to convert and disposition the } \\
\text { DUF }_{6} \text {. }\end{array}$ & $\begin{array}{l}\text { Issue open. } \\
\text { Issue would be resolved as a } \\
\text { part of DOE's evaluation of } \\
\text { the proposals for conversion } \\
\text { and disposition of its } \\
\text { inventory. }\end{array}$ \\
\hline $\begin{array}{l}\text { Historical NRC Views: The NRC } \\
\text { staff has formally expressed views to } \\
\text { the effect that large amounts of DU } \\
\text { product forms are not generally } \\
\text { acceptable for near-surface disposal. }\end{array}$ & $\begin{array}{l}\text { NRC views concerning the acceptability of DU products } \\
\text { for near-surface disposal and technical analyses underlying } \\
\text { these views may impact the disposal of DU products at } \\
\text { Envirocare. }\end{array}$ & $\begin{array}{l}\text { Issue open. } \\
\text { Issue would be resolved } \\
\text { between the state of Utah } \\
\text { and Envirocare if and when } \\
\text { it arises. }\end{array}$ \\
\hline $\begin{array}{l}\text { Reactivity: Waste acceptability at } \\
\text { Envirocare requires that it not be } \\
\text { "reactive." Most substances, including } \\
\text { DU products, react very slowly to form } \\
\text { other substances. A restrictive } \\
\text { interpretation of "reactive" could } \\
\text { render DU products unacceptable at } \\
\text { Envirocare. }\end{array}$ & $\begin{array}{l}\text { For a waste to be deemed "reactive," a visible, if not rapid, } \\
\text { reaction is required in water or air. This would clearly not } \\
\text { be the case for any of the DU product forms if they are } \\
\text { properly specified and manufactured (e.g., no high- } \\
\text { surface-area metal or } \mathrm{DUO}_{2} \text { powder). }\end{array}$ & Issue closed. \\
\hline $\begin{array}{l}\text { Mobile Radionuclides: Wastes } \\
\text { containing any amount of a list of } \\
\text { radionuclides that included }{ }^{99} \mathrm{Tc} \text { and } \\
{ }^{237} \mathrm{~Np} \text { had to be emplaced in specific } \\
\text { parts of the Low Activity Radioactive } \\
\text { Waste disposal cell. This could limit } \\
\text { the availability of disposal capacity. }\end{array}$ & $\begin{array}{l}\text { As a result of the new amendment to the Envirocare } \\
\text { license, Envirocare now has a new Class A cell. There are } \\
\text { no restrictions on where wastes can be buried in the new } \\
\text { Class A cell at Envirocare. }\end{array}$ & Issue closed. \\
\hline $\begin{array}{l}\text { NEPA: If appropriate NEPA review of } \\
\text { disposal of DU products at Envirocare } \\
\text { has not been performed, then DOE's } \\
\text { NEPA review of DUF }{ }_{6} \text { conversion and } \\
\text { disposition would have to cover } \\
\text { disposal at Envirocare. }\end{array}$ & $\begin{array}{l}\text { No federal agency action was involved in issuance of the } \\
\text { Envirocare radioactive material license, which authorizes } \\
\text { disposal of LLW in the Class A cell. Consequently, no } \\
\text { NEPA review was required. Notwithstanding, the Utah } \\
\text { Division of Radiation Control's radioactive material } \\
\text { licensing process appears to document many NEPA } \\
\text { values. Also, as appropriate, DOE will perform NEPA } \\
\text { review of transportation of DU to Envirocare. }\end{array}$ & Issue closed. \\
\hline
\end{tabular}




\section{INTRODUCTION}

An earlier report [Croff 2000] assessed preferences for various products that could result from the conversion of depleted uranium (DU) hexafluoride to a more stable chemical form to meet DOE's commitments in this regard [FR 1999]. Among other things, the earlier report contained a preliminary assessment of the acceptability of the potential DU products for near-surface disposal at the Envirocare facility in Clive, Utah, and the low-level waste (LLW) disposal facility at the Nevada Test Site. This assessment was based on previous knowledge of the authors and preliminary review of documents relevant to waste acceptance at these sites. The report's conclusion regarding the Envirocare site was that "the current waste acceptance criteria suggest that the acceptability of depleted uranium hexafluoride conversion material for disposal at Envirocare of Utah is questionable. Further investigation is required before a definitive determination can be made" [Croff 2000, p. 9]. The purpose of this report is to document the more thorough investigation suggested in the conclusion of the previous report.

The potential DU product forms considered in this report are DU tetrafluoride $\left(\mathrm{DUF}_{4}\right)$, DU sesquioxide $\left(\mathrm{DU}_{3} \mathrm{O}_{8}\right)$, DU dioxide $\left(\mathrm{DUO}_{2}\right)$, and DU metal. The amount of $\mathrm{DUF}_{6}$ to be converted to one or more of these product forms is about 700,000 metric tons (MT), which is equivalent to about 473,000 MT of elemental uranium. When converted the resulting DU product will have a volume of about $25,000 \mathrm{~m}^{3}$ if the product form is the metal and about $150,000 \mathrm{~m}^{3}$ for the other product forms, although there is a large range attached to the latter depending on the bulk density of the DU product.

The evaluation described in this report was performed as follows:

- Initial Issue Analysis: Documents relevant to disposal of potential DU products at Envirocare were analyzed to identify issues that could result in such disposal being impeded or untenable. The primary documents in this regard are the Envirocare Waste Acceptance Guidelines (WAGs) [Envirocare 1999], the Envirocare Radioactive Material License (RML), amendment 10 [Envirocare 1998], and the relevant regulations of the state of Utah [Utah 2000]. These issues were analyzed to provide the basis for subsequent fact finding.

- Fact Finding: A team composed of DOE and DOE contractor representatives met with Envirocare staff to discuss the issues and tour the site. DOE contractor representatives also met with a representative of the Division of Radiation Control (DRC), which is the state of Utah's cognizant regulatory organization for disposal of radioactive materials.

- Initial Issue Evaluation: The results of the analysis and site visits were evaluated, leading to an initial 
view on the status of the issues.

- Follow-Up: Additional information was sought to clarify questions that arose during the initial evaluation.

- Review and Resolution: The report was reviewed by DOE, DOE contractor, Envirocare, and Utah DRC staff. Revisions were made based on the review comments yielding this report.

The issue identification process resulted in the list that follows, which constitutes the framework for the remainder of this report:

- License Receipt Limits (LRLs) that define the maximum activity concentration of DU and progeny assumed to be in equilibrium with it (pCi/g DU product) that is acceptable at Envirocare.

- Determination that the DU products are Class A LLW.*

- $\quad$ Obtaining an exemption to dispose of the DU products at Envirocare as required by DOE Order 435.1 given the recent Record of Decision (ROD) [FR 2000] designating the Nevada Test Site and Hanford as preferred disposal sites for DOE LLW.

- Statements of the NRC suggesting that large amounts of concentrated DU are not generally acceptable for near-surface disposal.

- Requirements that the DU product undergo pre-shipment screening tests for water and air reactivity.

- Limitations on disposal of wastes containing "mobile" radionuclides.

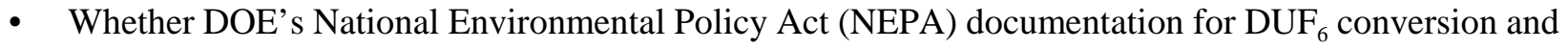
disposition would have to cover disposal activities at Envirocare.

The following were determined to not be issues regarding DU product disposal at the Envirocare site:

- Potential generation of HF from the interaction of water with $\mathrm{DUF}_{4}$. In the WAG, such generation is deemed relevant only if it could harm personnel transporting, handling, or disposing of the DU product. These operations would involve sealed containers (e.g., drums, large polymer bags for bulk amounts) of DU product which would preclude the contact with water necessary to generate the HF.

*Envirocare has a pending application to accept Class B and Class C LLW. 
- Criticality issues and limits on the concentrations of special nuclear materials (SNM). Because the DU product will have a lower-than-natural concentration of ${ }^{235} \mathrm{U}$, it is, by definition, not SNM.

- License Receipt Limits (LRLs) for any radionuclide other than isotopes of uranium. Bounding concentrations of other trace radionuclides such as ${ }^{99} \mathrm{Tc}$ and transuranic radionuclides are expected to be far below LRLs [Hightower 2000].

- Possibility of disposal capacity shortage at Envirocare. The capacity of the new Class A disposal cell at Envirocare is approximately 3.1 million cubic meters. Thus, the estimated volume of the bulkier DU products $\left(150,000 \mathrm{~m}^{3}\right)$ would only occupy about $5 \%$ of the available disposal volume.

\section{LICENSE RECEIPT LIMITS}

Initial Issue Analysis: There are concentration limits on a long list of radionuclides that may be present in wastes accepted for disposal in the low-activity radioactive waste (LARW) cell at Envirocare (LRLs). Among these is a limit of 370,000 pCi of DU per gram of waste. This limit is based on the activity of the DU per se but takes into account the impact of all progeny of DU decay in equilibrium with their longestlived parent.

Because the DU product form will include varying amounts of anions such as fluorine and oxygen, the amount of DU per unit of waste would vary from a high of $100 \%$ for DU metal to a low of $76 \%$ for DUF 4 .

The radioactivity of a gram of DU is composed of about $340,000 \mathrm{pCi}$ from ${ }^{238} \mathrm{U}$, plus the activity from ${ }^{234} \mathrm{U}$ and ${ }^{235} \mathrm{U}$ which are present in concentrations ranging from nearly zero to 55 and $7100 \mathrm{ppm}$, respectively. The concentrations of the two isotopes are strongly correlated. The latter two minor isotopes are much shorter lived than ${ }^{238} \mathrm{U}$ and thus have a disproportionally large impact on DU radioactivity compared with their concentration. The activity of the four potential DU product forms as a function of the concentration of ${ }^{235} \mathrm{U}$ in the tails is shown in Table 2. Based on the area shaded in Table 2, the Envirocare LRLs would be exceeded for about $5 \%,>36 \%,>62 \%$, and $>84 \%$ of the $\mathrm{DU}$ for $\mathrm{DUF}_{4}, \mathrm{DU}_{3} \mathrm{O}_{8}, \mathrm{DUO}_{2}$, and DU metal product forms, respectively.

\footnotetext{
*The report on preferred DU disposal forms [Croff 2000] incorrectly stated that the SNM concentration limit for waste accepted at Envirocare would be exceeded. This statement was in error because, while the ${ }^{235} \mathrm{U}$ activity in DU exceeds its specified limit, DU is not SNM by definition. Hence, the limit is not applicable.
} 
Table 2. Isotopic composition, mass, and activity of DU as a function of ${ }^{235} \mathrm{U}$ concentration

\begin{tabular}{|c|c|c|c|c|c|c|c|c|}
\hline & \multicolumn{8}{|c|}{ Concentration of ${ }^{235} \mathrm{U}$ in depleted uranium (wt \%) } \\
\hline & 0.1 & 0.225 & 0.275 & 0.325 & 0.375 & 0.425 & 0.579 & 0.709 \\
\hline DU form & \multicolumn{8}{|c|}{ Activity of depleted uranium, $\mathrm{pCi} / \mathrm{g}$ of DU form ${ }^{a}$} \\
\hline $\mathrm{UF}_{4}$ & 268,680 & 303,869 & 318,899 & 338,704 & 358,510 & 378,315 & 452,114 & 520,799 \\
\hline $\mathrm{U}_{3} \mathrm{O}_{8}$ & 300,582 & 339,948 & 356,763 & 378,920 & 401,077 & 423,234 & 505,795 & 582,635 \\
\hline $\mathrm{UO}_{2}$ & 312,633 & 353,578 & 371,067 & 394,112 & 417,158 & 440,203 & 526,074 & 605,995 \\
\hline Metal & 354,459 & 400,882 & 420,711 & 446,840 & 472,968 & 499,097 & 596,456 & 687,069 \\
\hline
\end{tabular}

$\checkmark$

\begin{tabular}{|c|c|c|c|c|c|c|c|}
\hline \multicolumn{8}{|c|}{ Inventory of depleted uranium, $\mu \mathrm{g}$} \\
\hline 70,960 & 102,218 & 118,765 & 79,400 & 61,299 & 14,737 & 7,305 & 75 \\
\hline \multicolumn{8}{|c|}{ Cumulative fraction of depleted uranium inventory, $\%$} \\
\hline 16 & 38 & 64 & 82 & 95 & 98 & 100 & 100 \\
\hline \multicolumn{8}{|c|}{ Isotopic composition of depleted uranium, $\mathrm{g}$ isotope/g $\mathrm{U}$} \\
\hline $2.00 \mathrm{E}-06$ & $9.00 \mathrm{E}-06$ & $1.20 \mathrm{E}-05$ & $1.60 \mathrm{E}-05$ & $2.00 \mathrm{E}-05$ & $2.40 \mathrm{E}-05$ & $3.90 \mathrm{E}-05$ & $5.30 \mathrm{E}-05$ \\
\hline $1.00 \mathrm{E}-03$ & $2.25 \mathrm{E}-03$ & $2.75 \mathrm{E}-03$ & $3.25 \mathrm{E}-03$ & $3.75 \mathrm{E}-03$ & $4.25 \mathrm{E}-03$ & $5.79 \mathrm{E}-03$ & $7.09 \mathrm{E}-03$ \\
\hline $9.99 \mathrm{E}-01$ & $9.98 \mathrm{E}-01$ & $9.97 \mathrm{E}-01$ & $9.97 \mathrm{E}-01$ & $9.96 \mathrm{E}-01$ & $9.96 \mathrm{E}-01$ & $9.94 \mathrm{E}-01$ & $9.93 \mathrm{E}-01$ \\
\hline
\end{tabular}

${ }^{a}$ Depleted uranium exceeding $370,000 \mathrm{pCi} / \mathrm{g}$ DU product form is indicated by the shaded area. 
As a consequence of the above, a significant-to-substantial fraction of potential DU products would not be acceptable for disposal at the Envirocare facility based on LRLs as expressed in the Envirocare RML, amendment 10 [Envirocare 1998].

Results of Envirocare Discussions: Subsequent to the issuance of the report [Croff 2000] calling for further investigation to determine the acceptability of potential DU forms for disposal at Envirocare, the state of Utah amended Envirocare's license [Envirocare 2000]. The new amendment 11 added provisions to the RML authorizing construction and operation of a new Class A disposal cell to which isotope-specific LRLs do not apply. Thus, the limitation that the isotope-specific LRLs contained in the RML, amendment 10, would have imposed on the disposal of DU in the Envirocare LARW cell has been eliminated for the Class A cell.

Results of State of Utah Discussions: The Utah DRC agreed that the isotope-specific LRLs are not applicable to waste buried in Envirocare's Class A cell.

Issue Resolution: As a result of the new amendment to the Envirocare license, DU products could be buried in the Class A cell at Envirocare because the isotope-specific LRLs do not apply to wastes to be buried in this cell. This issue is closed.

\section{CLASSIFICATION OF DU PRODUCTS}

Initial Issue Analysis: For a waste to be acceptable for disposal at Envirocare, it must be classified as Class A LLW, as defined in Section R313-15-1008 of the Code of the State of Utah [Utah 2000]. A relatively short list of radionuclides is considered to determine whether candidate waste is Class $\mathrm{A}$. The only radionuclide on this list of significance to disposal of DU product forms is the ${ }^{226} \mathrm{Ra}$ decay product of ${ }^{238} \mathrm{U}$, the Class A limit for which is $10,000 \mathrm{pCi}$ per gram of DU product form.

The ${ }^{226} \mathrm{Ra}$ concentration, and thus its activity in the DU product, is essentially zero at the time the product would be generated by conversion of $\mathrm{DUF}_{6}$. However, radioactive decay increases the concentration of ${ }^{226} \mathrm{Ra}$ to the Class A limit (10,000 pCi/g DU product) in about 50,000 years, to the Class C limit $(100,000 \mathrm{pCi} / \mathrm{g})$ 
in about 200,000 years, and ultimately to $340,000 \mathrm{pCi} / \mathrm{g} \mathrm{DU}$ product, at which point it is in secular equilibrium with the ${ }^{238} \mathrm{U}$ in DU.

The time at which the activity of ${ }^{226} \mathrm{Ra}$ is determined is not specified in the state of Utah regulations. However, Sect. 4.2.3 of the Envirocare WAGs, which pertains to LRLs (not waste classification), states "The LRLs assumes short-lived daughter products [such as ${ }^{226} \mathrm{Ra}$ ] are present in equilibrium with their long-lived parents." If waste classification must use ${ }^{226} \mathrm{Ra}$ concentrations that are in equilibrium with ${ }^{238} \mathrm{U}$, then the DU products would exceed Class A and Class C limits.

Results of Envirocare Discussions: The view of Envirocare is that applicable regulations are interpreted to mean that (a) the concentration of ${ }^{226} \mathrm{Ra}$ relevant to classification is determined at the time the waste is received and (b) the concentration limits already account for the ingrowth of shorter-lived progeny. Thus, the Class A concentration limits for ${ }^{226} \mathrm{Ra}$ would be easily met.

Results of State of Utah Discussions: The Utah DRC agreed with Envirocare on the issue of classification; that is, that classification of the DU is based on the composition at the time of waste receipt.

Issue Resolution: Determination of whether waste is Class A LLW is based on the waste composition when received by Envirocare. The only component of DU that could limit its being Class A is ${ }^{226} \mathrm{Ra}$. At the time of receipt by Envirocare, DU products would easily meet the ${ }^{226} \mathrm{Ra}$ concentration limits. This issue is closed.

\section{ACCESS TO NON-DOE LLW DISPOSAL SITES}

Initial Issue Analysis: In its recent Record of Decision [FR 2000], DOE decided to continue on-site disposal of LLW at a number of DOE sites to the extent practicable and to make the Hanford Site in Washington and the Nevada Test Site available to all DOE sites for LLW disposal.

However, the decision to make LLW disposal at the Nevada Test Site and the Hanford Site available to all DOE sites does not preclude DOE's use of commercial disposal facilities, consistent with current DOE policy [DOE 1999a] and DOE Order 435.1 concerning management of DOE's wastes and its associated manual concerning implementation [DOE 1999b]. The key requirements in this regard are as follows: 
DOE M 435.1-1 I.F. Field Element Managers. Field Element Managers are responsible for:

(4) Approval of Exemptions for Use of Non-DOE Facilities. DOE radioactive waste shall be treated, stored, and in the case of low-level waste, disposed of at the site where the waste is generated, if practical; or at another DOE facility. If DOE capabilities are not practical or cost effective, exemptions may be approved to allow use of non-DOE facilities for the storage, treatment, or disposal of DOE radioactive waste based on the following requirements:

(a) Such non-DOE facilities shall:

1. Comply with applicable Federal, State, and local requirements;

2. Have the necessary permit(s), license(s), and approval(s) for the specific waste(s); and

3. Be determined by the Field Element Manager to be acceptable based on a review conducted annually by DOE.

(b) Exemptions for the use of non-DOE facilities shall be documented to be cost effective and in the best interest of DOE, including consideration of alternatives for on-site disposal, an alternative DOE site, and available non-DOE facilities; consideration of life-cycle cost and potential liability; and protection of public health and the environment.

(c) DOE waste shall be sufficiently characterized and certified to meet the facility's waste acceptance criteria.

(d) Appropriate National Environmental Policy Act (NEPA) review must be completed. For actions taken under the Comprehensive Environmental Response, Compensation, and Liability Act (CERCLA), it is DOE's policy to incorporate NEPA values into the CERCLA documentation.

(e) Headquarters shall be notified of any exemption allowing use of a non-DOE facility and the Office of the Assistant Secretary for Environment, Safety and Health (EH-1) shall be consulted prior to the exemption being executed.

(f) Host States and State Compacts where non-DOE facilities are located shall be consulted prior to approval of an exemption to use such facilities and notified prior to shipments being made.

Detailed guidance on the multistep process required to demonstrate compliance with the requirements stated above and considerations involved in implementing the process are described in the Implementation Guide for use with DOE M 435.1 [DOE 1999c].

In summary, while disposal of DOE's LLW at commercial sites is possible, there are requirements to show that such an activity is cost-effective and to consult with multiple stakeholders, including other elements of DOE, the host state, and the host state compact."

Results of Envirocare Discussions: Envirocare agreed with the validity of the issue but noted that it has

\footnotetext{
*The state of Utah is a member of an LLW compact with a number of other states in the northwestern United States.
} 
about a dozen existing exemptions from the DOE Oak Ridge Operations Office for disposal of various LLW streams. A joint observation was that during the last year, the intensity of scrutiny concerning exemptions has increased, as evidenced by DOE's formal call for case-by-case rejustification of existing exemptions. This was attributed to publication of the ROD, which completes the programmatic NEPA review necessary to support DOE's decision to dispose of DOE LLW from many sites at the Nevada Test Site and the Hanford Site.

Resolution of this issue as it concerns future disposal of DU product forms lies with the Manager of the DOE Oak Ridge Operations Office, although concurrence of some DOE headquarters elements is also required. It is assumed that ensuring compliance with exemption requirements as stated above and granting of the

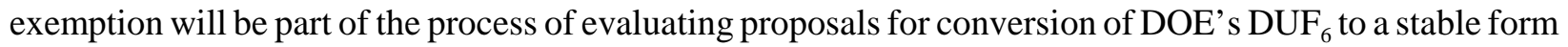
and subsequent disposition of the resulting DU products.

Results of State of Utah Discussions: The issue was noted but, because it does not involve the state of Utah, there are no relevant results.

Issue Resolution: Issue not closed. The issue of granting an exemption to the DOE Order requirement to use a DOE site for disposal of the DU product will presumably be resolved as a part of DOE's evaluation of the proposals for conversion and disposition of DOE's DUF ${ }_{6}$ inventory.

\section{HISTORICAL VIEWS OF THE U.S. NUCLEAR REGULATORY COMMISSION}

Initial Issue Analysis: In the matter of the Louisiana Energy Services, L.P. (LES) application for an NRC license to construct and operate a uranium enrichment plant in Claiborne Parish, Louisiana (Claiborne Enrichment Center), the NRC staff analyzed land disposal of DU. In 1992, the NRC staff expressed a preference for $\mathrm{U}_{3} \mathrm{O}_{8}$ as the chemical form for final disposition and advised LES that disposal as DUF 4 in a licensed 10 CFR Part 61 shallow land disposal facility located in a humid environmental setting would not be acceptable "because the physicochemical, long-term stability [of DUF 4 ] is incompatible with final disposal under 10 CFR Part 61" [NRC 1992]. In the Claiborne Enrichment Center Final Environmental Impact Statement (EIS), the NRC staff again recommended against land disposal of $\mathrm{DUF}_{4}$, stating that its reaction with water could produce quantities of HF that could compromise the integrity of a disposal facility and 
significantly disturb the environment [NRC 1994]. The Final Claiborne Enrichment Center EIS also concluded that near-surface disposal of $\mathrm{DU}_{3} \mathrm{O}_{8}$ in a humid environmental setting would not comply with 10 CFR Part 61 performance objectives and suggested that deep disposal of some type might be necessary [NRC 1994, Appendix A]. In 1995, during the scoping process for DOE's Programmatic Environmental Impact Statement (PEIS) [DOE 1999a] concerning long-term management of DUF 6 , the NRC staff repeated its opinion that $\mathrm{DU}_{3} \mathrm{O}_{8}$ is a likely chemical form for DU disposal. However, they also advised DOE that, although $\mathrm{DU}_{3} \mathrm{O}_{8}$ could be disposed of in limited quantities in conventional near-surface disposal facilities, large quantities (such as would be derived from the nation's enrichment tailings inventory) suggest the possible need for a unique disposal facility, such as a mined cavity or an exhausted uranium mine [NRC 1995].

The previous paragraph describes NRC staff opinions that are not binding in any specific licensing proceeding conducted by either the NRC or an agreement state, such as the state of Utah. Even so, the Utah Division of Radiation Control (DRC), which is the responsible regulatory agency under Utah's agreement with the NRC, may decide to adopt in whole or in part the NRC staff opinions regarding the acceptability of DU forms for near-surface disposal at the Envirocare facility. Thus, further discussions with Envirocare and the Utah DRC are needed to gain more insight into uncertainties raised by the NRC staff opinions reported above.

Results of Envirocare Discussions: Envirocare has seen no evidence that the views of the NRC summarized above are shared by the Utah DRC. In reviewing Envirocare's application for the October 5, 2000, RML amendment, which authorized receipt of all types and quantities of Class A waste for placement in the Class A disposal cell, the DRC required demonstrations of compliance with the Utah groundwater protection standard of $4 \mathrm{mrem} / \mathrm{year}$ and annual radiation exposure standards for members of the public. Envirocare was able to demonstrate compliance with these standards, which they believe are more restrictive than the NRC radiation protection limits for members of the public. Hence, even though the potential always exists for the DRC to adopt the NRC's position in the future, Envirocare does not believe there is any DRC sentiment against near-surface disposal of DU.

Results of State of Utah Discussions: The Utah DRC was not aware of the NRC staff opinions, and although there is frequent contact between the DRC and the NRC, this issue has not arisen. The state of Utah does not routinely approve each waste stream accepted at Envirocare for disposal but would do so for DU if (a) 
Envirocare requested the DRC's concurrence with Envirocare's review of the DU product, (b) if the generator of the DU product requests that the Utah DRC become involved, or (c) the Utah DRC receives other information that indicates they should be involved.

It was noted that the performance assessment for Envirocare's Class A disposal cell license amendment [Envirocare 2000] was based on a spectrum of LLW typical of wastes accepted at other commercial LLW disposal sites and the potentially large amount of DU product now being considered for disposal was not encompassed in this spectrum of waste. It was also noted that the performance assessment for Envirocare's Class A cell takes the shorter-lived progeny of DU into account. The assessment assumes that active institutional controls cease 100 years after closure, that compliance with state of Utah groundwater protection standards ( 4 mrem/year) must be met 1000 years after site closure, and that releases must be predicted out to 10,000 years after site closure. The DRC indicated that the views of the NRC and the technical bases underlying them, including the atypical nature of the DU product as compared with the basis used for the Envirocare performance assessment, would need to be considered by Envirocare when evaluating the acceptability of the DU product for disposal.

Issue Resolution: Issue not closed. The potential for the views of the NRC staff concerning the acceptability of DU products for near-surface disposal and technical analyses underlying these views to impact the disposal of DU products at Envirocare exists. This issue will presumably be resolved between the state of Utah and Envirocare if and when disposal of the DU product at Envirocare is imminent, although the issue could be raised by the generator of the DU product.

\section{PRE-SHIPMENT SCREENING FOR REACTIVITY}

Initial Issue Analysis: Section 5.1 of the Envirocare WAGs explains that a three-part process has been adopted to verify compliance with the provisions of the RML. The three parts of the verification process are (1) profiling, (2) pre-shipment screening analysis, and (3) periodic receipt analysis. One RML provision that is part of this verification process requires that the waste not be capable of reaction in air at normal pressures and temperatures, or of explosive reaction with water. During the profiling stage of the process, waste generators must characterize each waste, including its capability to react with air and water, on a Waste Profile Record. During the pre-shipment screening stage of compliance verification, the test protocol used 
by Envirocare to screen for the capability to undergo explosive reaction with water is to place a small portion of the waste in water. "If the material ignites, reacts, or the temperature rises dramatically, the waste is considered reactive, and may be deemed unacceptable for disposal"(Envirocare 1999). The protocol used by Envirocare to screen a waste for air reactivity is similar to that for water and involves exposure to air for 5 min. Beyond the protocol descriptions in the WAGs, there is no definition of the term "reacts" in the WAGs or RML.

Essentially all materials, including all the potential DU product forms, react at some rate with water and air. These reactions are slow (i.e., not observable without instrumentation) but are finite nevertheless. Hence, if Envirocare or the state of Utah should adopt an extremely restrictive interpretation of "react" for the purpose of pre-shipment screening analysis, the result may be to preclude disposal of some or all of the DU product forms at Envirocare.

Results of Envirocare Discussions: Neither Envirocare nor the Utah DRC has adopted a restrictive interpretation of "reactive," and there is no evidence this will change in the future. In particular, "reactive" is interpreted to mean that the reaction rate is at least visible, if not rapid, within the short duration of the test.

Results of State of Utah Discussions: The state of Utah indicated that they interpreted "reactive" as stated by Envirocare.

Issue Resolution: For a waste to be deemed "reactive," a visible, if not rapid, reaction in water or air must occur. This would not be the case for any of the DU product forms if they are properly specified and manufactured (e.g., no high-surface-area metal or $\mathrm{DUO}_{2}$ powder). Thus, this issue is closed. 


\section{MOBILE RADIONUCLIDES}

Initial Issue Analysis: Condition 42 of the Envirocare RML defines "mobile wastes" as “ . . any waste containing any [emphasis added] quantity of the following isotopes: carbon-14, iodine-129, neptunium-237, sodium-22, technetium-99 ..." The DU products are expected to contain extremely low but measurable concentrations of ${ }^{237} \mathrm{~Np}$ and ${ }^{99} \mathrm{Tc}$ which resulted from the recycle of uranium recovered from target and fuel processing in the uranium enrichment plants. Secondary wastes from conversion (e.g., from washing heel material from cylinders) could contain appreciable concentrations of ${ }^{237} \mathrm{~Np}$ and ${ }^{99} \mathrm{Tc}$.

Disposal of mobile wastes is allowed at Envirocare, but the wastes must be emplaced in specific areas of the LARW disposal cell. The volume of DU product that may be considered mobile waste is about $25,000 \mathrm{~m}^{3}$ (120,000 drums) for a DU metal product form and about $150,000 \mathrm{~m}^{3}(720,000$ drums $)$ for the other candidate product forms. The disposal space available for mobile wastes is unknown, and it is possible that the large amount of DU products that could require disposal might exceed the space available in the LARW disposal cell.

Results of Envirocare Discussions: Subsequent to the issuance of the report [Croff 2000] calling for further investigation to determine the acceptability of potential DU forms for disposal, the state of Utah amended Envirocare's license [Envirocare 2000]. This amendment includes new provisions that authorized construction and operation of a new Class A disposal cell that is separate from the LARW cell. Limitations on the presence of mobile radionuclides per se were not included as a restriction on where wastes can be emplaced in the Class A cell.

Results of State of Utah Discussions: The state of Utah confirmed Envirocare's interpretation of the amendment as stated above.

Issue Resolution: As a result of the October 5, 2000, amendment to the Envirocare license, there are no restrictions on where wastes can be buried in the Class A cell at Envirocare. This issue is closed. 


\section{NATIONAL ENVIRONMENTAL POLICY ACT}

Initial Issue Analysis: DOE M 435.1-1, Section I.F(4) establishes exemption criteria to be used by the responsible DOE Field Element Manager (who is the Manager of the DOE Oak Ridge Operations Office in the case of DU conversion and management) for evaluating whether to allow the use of non-DOE facilities for storage, treatment, or disposal of DOE radioactive waste. These criteria include the requirement to complete appropriate NEPA reviews [DOE 1999b, Section I.F(4)(d)].

As a commercial radioactive waste disposal facility, Envirocare operates its Class A LLW disposal cell under Radioactive Material License No. UT 2300249, Amendment \#11 [Envirocare 2000], issued by the Utah DRC. Since no federal agency action was involved in issuing this license, no NEPA review was required. The extent to which this might be an impediment to approval of an exemption for disposal of DU product forms at Envirocare is unclear.

Results of Envirocare Discussions: In the past, the Manager of the DOE Oak Ridge Operations Office has approved disposal of other DOE LLW streams at Envirocare. In such cases, DOE performed appropriate NEPA analyses regarding the actions generating the LLW and the methods to be used in transporting the LLW to the Envirocare site. NEPA review of disposal of the specific waste streams at the Envirocare site was not raised as an issue. In addition, the NRC has granted Agreement State status to the state of Utah. In doing so, the NRC determined, among other things, that Utah's radiation protection regulations applicable to licensing of the Envirocare LLW disposal facility are equivalent to federal LLW disposal regulations in 10 CFR Part 61. Therefore, Envirocare believes that the Utah licensing process under which its RML was issued has been determined by the NRC to be functionally equivalent to the NEPA review process that would otherwise be followed if the NRC issued a LLW disposal license under 10 CFR Part 61.

Results of State of Utah Discussions: Utah has not adopted a state environmental policy act similar to the federal NEPA. Notwithstanding, the DRC LLW disposal facility licensing process, which applies to Envirocare's RML, includes steps which reflect such NEPA values as notice of proposed agency action, opportunity for public comment, agency response to public comments, opportunity for public hearings, notice of final agency action, and opportunity for judicial review (see Utah Administrative Code R313-17, Administrative Procedures). In addition, Envirocare conducts waste disposal operations at its site for radioactive wastes classified as by-product materials pursuant to section 11.e(2) of the Atomic Energy Act 
of 1954 (42 U.S.C. 2014(e)(2)) (i.e., uranium and thorium mill tailings). Disposal of such wastes requires a separate license issued by the NRC (rather than the DRC), which Envirocare has obtained. In support of the decision to issue the license for disposal of section 11.e(2) by-product material at the Envirocare facility, the NRC conducted a NEPA review. Hence, considering the nature of the state and federal licensing reviews that have been performed to authorize disposal of radioactive wastes in quantities and types that encompass the DU products, Utah believes it is likely that a demonstration could be made, if necessary, that NEPA values have been adequately documented for disposal of the DU products at Envirocare.

Issue Resolution: No NEPA review was conducted in support of the RML amendment authorizing disposal of DU in the Envirocare Class A cell, because no federal action was involved. In addition, in spite of the close proximity of the 11.e(2) cell and the Class A cell, the NEPA review conducted during the NRC's 11.e(2) byproduct material licensing process is unlikely to contain analyses pertinent to disposal of DU products because of the length of time (approximately six years) between issuance of the 11.e(2) byproduct material license and issuance of the amendment to the RML approving the Class A LLW cell. However, it appears that many NEPA values concerning disposal of LLW were documented during the State's LLW disposal facility licensing process. In addition, DOE field elements, including the Oak Ridge Operations Office, have not historically questioned the adequacy of the Utah LLW disposal facility licensing process to support approving disposal of DOE LLW at the Envirocare facility. This suggests that the absence of an actual NEPA review of DU disposal at the Envirocare facility is not likely to be an impediment to meeting the criterion in DOE M 435.1-1, Section I.F(4)(d). Of course, in order for this criterion to be fully met, so that an exemption may be approved to allow use of the Envirocare facility for DU disposal, DOE must complete the appropriate NEPA review for transportation of the DU products to the Envirocare facility. This issue is considered to be closed because such NEPA review is already planned. 


\section{REFERENCES}

Croff 2000. A. G. Croff, J. R. Hightower, D. W. Lee, G. E. Michaels, N. L. Ranek, and J. R. Trabalka, Assessment of Preferred Depleted Uranium Disposal Forms, ORNL/TM-2000/16, June 2000.

DOE (U.S. Department of Energy) 1999a. "Commercial Disposal Policy Analysis for Low-Level and Mixed Low-Level Wastes," Office of Environmental Management, March 9, 1999.

DOE (U.S. Department of Energy) 1999b. "Radioactive Waste Management Manual," Office of Environmental Management, DOE M 435.1-1, July 9, 1999.

DOE (U.S. Department of Energy) 1999c. "Implementation Guide for Use with DOE M 435.1-1," Office of Environmental Management, DOE G 435.1-1, July 9, 1999.

FR (Federal Register) 1999. "Record of Decision for Long-Term Management and Use of Depleted Uranium Hexafluoride," Fed. Reg. 43358, 64(153), August 10, 1999.

FR (Federal Register) 2000. "Record of Decision for the Department of Energy's Waste Management Program: Treatment and Disposal of Low-Level Waste and Mixed Low-Level Waste; Amendment of the Record of Decision for the Nevada Test Site," 65 FR 10061-10066, February 25, 2000.

Envirocare (Envirocare of Utah, Inc.) 1998. Radioactive Material License for Envirocare of Utah, Inc., License Number UT 2300249, Amendment 10, http://www.envirocareutah.com, September 25, 1998.

Envirocare (Envirocare of Utah, Inc.) 2000. Radioactive Material License for Envirocare of Utah, Inc., License Number UT 2300249, Amendment 11, http://www.envirocareutah.com, October 5, 2000.

Envirocare (Envirocare of Utah, Inc.) 1999. Waste Acceptance Guidelines, Envirocare of Utah, Inc., Rev. 2, http://www.envirocareutah.com, September 30, 1999.

Hightower, J. R., et al. 2000. Strategy for Characterizing Transuranics and Technetium Contamination in Depleted $U_{6}$ Cylinders, Oak Ridge National Laboratory, ORNL/TM-2000/242, October 2000. 
NRC (U.S. Nuclear Regulatory Commission) 1992. Letter from J. W. N. Hickey, NRC, to W. H. Arnold, Louisiana Energy Services L.P. on depleted uranium disposition, September 22, 1992.

NRC (U.S. Nuclear Regulatory Commission). 1994, "Final Environmental Impact Statement for the. Construction and Operation of Claiborne Enrichment Center, Homer, Louisiana," Docket No, 70-3070, NUREG-1484, vols. 1 and 2, Office of Nuclear Material Safety and Safeguards, Washington, D.C.

NRC (U.S. Nuclear Regulatory Commission) 1995. Letter from NRC (R. Bernero) to DOE (C. Bradley, Jr.), January 3, 1995.

Utah (State of Utah) 2000. Utah Radiation Control Rules R313-12 through R313-70 http://www.eq.state.ut.us/eqrad/rules/rules.htm, June 28, 2000. 

ORNL/TM-2000/355

\section{INTERNAL DISTRIBUTION}

$\begin{aligned} \text { 1. } & \text { J. M. Begovich } \\ 2 . & \text { J. B. Clendenen } \\ 3-4 . & \text { A. G. Croff } \\ 5 . & \text { L. R. Dole } \\ 6 . & \text { J. J. Ferrada } \\ 7 . & \text { M. J. Haire } \\ 8-12 . & \text { J. R. Hightower, Jr } \\ \text { 13. } & \text { C. M. Kendrick } \\ \text { 14. } & \text { D. W. Lee } \\ 15 . & \text { G. T. Mays }\end{aligned}$

16. G. E. Michaels

17. M. I. Morris

18. D. G. O'Connor

19. R. L. Reid

20. J. R. Trabalka

21. K. A. Williams

22. Central Research Library

23. ORNL Laboratory Records-RC

24. ORNL Laboratory Records-OSTI

\section{EXTERNAL DISTRIBUTION}

25. G.W. Benedict, DOE, Oak Ridge Operations Office, 200 Adminstration Road, Oak Ridge, TN 37831

26. L. D. Boggs, DOE, Oak Ridge Operations Office, 200 Adminstration Road, Oak Ridge, TN 37831

27. J. R. Gasper, Environmental Assessment Division, Argonne National Laboratory, Suite 6000, 955 L'Enfant Plaza S.W., Washington, DC 20024

28. R. M. Knipp, U.S. Department of Energy, Immediate Office of the Director, NE-1, Room 5A157, 1000 Independence Avenue, S.W., Washington, DC 20585

29. M. J. Letourneau, EM-22, Room 1099, Cloverleaf Building, 19901 Germantown Road, Germantown, MD 20874

30. S. R. Martin, DOE, Oak Ridge Operations, P.O. Box 2008, Oak Ridge, TN 37831-6269

31-32. N. L. Ranek, Environmental Assessment Division, Argonne National Laboratory, Suite 6000, 955 L'Enfant Plaza S. W., Washington, DC 20024

33. Robert R. Price, U.S. Department of Energy, NE-20, Room E-461, 19901 Germantown Road, Germantown, MD 20874-1290.

34-39. K. M. Shaw, U.S. Department of Energy, Office of Depleted Uranium Hexafluoride, NE-30, Room E-475, 19901 Germantown Road, Germantown, MD 20874-1290.

40. P. I. Stumbo, DOE, Oak Ridge Operations Office, 200 Administration Road, Oak Ridge, TN 37831

41. J. E. Rhoderick, EM-22, Room 1183, Cloverleaf Building, 19901 Germantown Road, Germantown, MD 20874

42-46. A. F. Tavares, U.S. Department of Energy, Office of Depleted Uranium Hexafluoride, NE-30 Room 1I-062, 1000 Independence Avenue, S. W., Washington, DC 20585

47. D. W. Tonkay, EM-22, Room 1206, Cloverleaf Building, 19901 Germantown Road, Germantown, MD 20874

48. D. K. Wierwille, DOE, Oak Ridge Operations Office, Room G 126-3, Federal Office Building, 200 Administration Road, Oak Ridge, TN 37831

49. D. L. Finerfrock, State of Utah Department of Environmental Quality, Division of Radiation Control, 168 North 1950 West, Salt Lake City, UT 84114-4850

50. S. P. Rice, Envirocare of Utah, Inc., 46 West Broadway, Suite 116, Salt Lake City, UT 84101. 